\title{
Implementasi Pembinaan Pengelolaan Arsip di Dinas Perpustakaan dan Arsip Kabupaten Tangerang
}

\author{
Cynthia Calista Herlambang Putri ${ }^{1}$ \& Siti Maryam \\ UIN Syarif Hidayatullah ${ }^{1}$ \\ cynthiacalistahp@gmail.com
}

\begin{abstract}
Purpose of this study to find out the Analysis of Management Archives Coaching by Tangerang District Library and Archives Services. This type of research uses a descriptive qualitative research approach. Data collection techniques, namely interviews with 5 (five) informants, observation, and documentation. While data analysis techniques include data reduction, data presentation, and drawing conclusions. The results of the study can be concluded that the activities of archiving guidance carried out by the Tangerang District Disperpusip begins with the stages of planning, coordination, preparation of materials for archiving development, and the implementation of archiving guidance activities which are divided into two types, namely technical guidance conducted classically to OPD (Regional Apparatus Organization) ) and direct assistance to the archives manager in the village. The technical guidance activity began with gathering archive managers from each OPD namely the Office and Agency after that the activity continued with the delivery of material classically with the theme "Dynamic Archive Management, That is Depreciation With the Focus of Moving Archives". In addition, the assistance was carried out by selecting archive managers from two to three villages and continued by providing direct training on how to organize files properly with the theme "Active Dynamic Archive Management". The obstacles faced in the activities of fostering archives are Human Resources and Archive management.
\end{abstract}

Keywords: Coaching, Archive, Regional Archive Institution 


\section{Pendahuluan}

Arsip sering digunakan sebagai alat komunikasi berupa informasi dan bukti otentik. Arsip dibedakan menjadi dua macam yaitu arsip dinamis dan arsip statis. Arsip dinamis yaitu arsip yang masih dipergunakan secara langsung dalam menyusun perencanaan, pelaksanaan, penyelenggaraan pelayanan pada umumnya atau dalam penyelenggaraan pelayanan ketatausahaan (Basuki, 1996:26).

Penyelenggaraan kearsipan nasional dalam Undang-Undang Nomor 43 Tahun 2009 tentang Kearsipan, pengelolaan arsip statis dan pembinaan kearsipan dilaksanakan oleh lembaga kearsipan sesuai wilayah kewenangannya yang terbagi menjadi empat macam yakni Arsip Nasional Republik Indonesia atau ANRI, arsip daerah provinsi, arsip daerah kabupaten/kota, dan arsip perguruan tinggi. Pemerintah daerah dalam urusan penyelengaraan arsip bertugas melaksanakan tugas pemerintahan dibidang kearsipan sesuai Pasal 25 UU Nomor 43 Tahun 2009 yakni, selain kewajiban Pasal 24 ayat (4) terkait pengelolaan arsip yang diterima dari lembaga sektor publik, arsip daerah kabupaten/kota memiliki tugas melaksanakan:
1. pengelolaan arsip inaktif dengan retensi paling sedikit 10 (sepuluh) tahun yang berasal dari satuan kerja perangkat daerah kabupaten/kota

2. penyelenggara pemerintahan daerah kabupaten/kota dan pembinaan kearsipan terhadap pencipta arsip di lingkungan daerah kabupaten/kota.

Dinas Perpustakaan dan Arsip Kabupaten Tangerang atau yang disingkat Disperpusip Kabupaten Tangerang sebagai salah satu contoh dari lembaga arsip daerah kabupaten/kota yang mengelola arsip statis dan melaksanakan kegiatan pembinan kearsipan, mencakup arsip-arsip yang berada di Organisasi Perangkat Daerah (OPD) Kabupaten Tangerang Badan Usaha Milik Daerah, perusahaan, organisasi politik, organisasi kemasyarakatan dan/atau perseorangan yang ada di ruang lingkup Kabupaten Tangerang.

Kegiatan pembinaan kearsipan Disperpusip Kabupaten Tangerang dilakukan berdasarkan Peraturan Pemerintah Republik Indonesia No. 28 tahun 2012 tentang Pelaksanaan UU No. 43/ 2009 tentang Kearsipan pasal 11 serta Peraturan Bupati No. 1 Tahun 2015 tentang Penyelenggaraan Kearsipan pada Bab IX tentang Pembinaan, Pengawasan, dan Pengendalian Pasal 85 ayat 1 dan 2 
yakni: 1) Kantor melaksanakan pembinaan terhadap Pencipta Arsip di lingkungan Pemerintah Daerah 2) Kepala SKPD melaksanakan pembinaan Kearsipan pada Unit Pengolah di lingkungan SKPD masing-masing. Kegiatan ini diselenggarakan untuk mengamankan Arsip Pemerintah Daerah sebagai bagian yang tidak terpisahkan dari bahan pertanggungjawaban nasional.

Kegiatan pembinaan yang dilakukan oleh Disperpusip Kabupaten Tangerang yakni dalam bentuk bimbingan teknis dan pendampingan yang mana kegiatan ini dibagi menjadi dua kegiatan yang berbeda dengan target yang berbeda pula. Bimbingan teknis dilakukan kepada OPD yakni Dinas dan Badan yang dilakukan dengan cara klasikal dengan jangka waktu tertentu. Sedangkan pembinaan kearsipan dalam bentuk bimbingan teknis juga dilakukan dengan cara klasikal namun disertai dengan kegiatan pendampingan yakni praktek yang dilakukan secara langsung kepada pengelola arsip yang ada di kantor desa/kelurahan dan kecamatan di hari yang berbeda.

Selain di OPD, kegiatan pembinaan kearsipan dalam bentuk bimbingan teknis dan pendampingan juga dilakukan di kantor desa/kelurahan.
Salah satu desa yang menjadi target dari kegiatan tersebut yakni Desa Bitung Jaya dan Kelurahan Bunder yang berada di Kecamatan Cikupa.

Berdasarkan observasi penulis dalam keikutsertaannya pada kegiatan pembinaan kearsipan dalam bentuk pendampingan di desa/kelurahan, dapat ditemui minimnya tenaga serta pengetahuan pengelola arsip dalam melaksanakan kegiatan pengelolaan arsip diruang lingkup kerja mereka, serta manajemen pengelolaan arsip yang belum sesuai dengan standar pengelolaan arsip yang baik, sehingga menyebabkan terjadinya banyak ketidaksesuaian dalam pengelolaan arsip mereka. Dari uraian di atas, tulisan ini membahas bagaimana kegiatan pembinaan pengelolaan arsip yang dilakukan oleh Disperpusip Kabupaten Tangerang dengan cara bimbingan teknis dan pendampingan.

\section{Tinjauan Pustaka}

\section{Pengertian Arsip dan Kearsipan}

Secara keseluruhan, kegiatan organisasi pada dasarnya membutuhkan sebuah informasi. Oleh karena itu salah satu sumber informasi penting yang dapat menunjang proses kegiatan administrasi maupun birokrasi adalah arsip. 
Arsip atau warkat inilah yang sangat berperan penting dalam kehidupan sehari-hari sebagai alat bukti otentik yang dapat dipertanggungjawabkan keasliannya. Arsip ini dibuat dan disimpan oleh sebuah lembaga pemerintah atau swasta, organisasi maupun individu sebagai alat komunikasi yang direkam dalam berbagai berbentuk dan media.

Arsip atau dalam bahasa inggris disebut "Archive" merupakan semua catatan dalam bentuk dan media apapun yang berisikan informasi mengenai sebuah persoalan ataupun peristiwa (Barthos, 2012:1). Sedangkan menurut Basuki (1996:1), arsip adalah hasil dari rekaman informasi yang dibuat oleh lembaga, organisasi, atau perorangan dalam melaksanakan kegiatan keorganisasiannya.

Arsip adalah hal yang sangat mendasar dalam kelangsungan hidup organisasi tersebut, yang mana arsip tidak dapat tergantikan oleh apa pun. Hal ini dikarenakan arsip memiliki nilai pembuktian secara hukum, kepemilikan, sejarah, dan lain-lain.

Barthos (2012:2) juga mengungkapkan bahwa kearsipan adalah kegiatan pengelolaan arsip yang dimulai dari pencatatan hingga pemeliharaan arsip yang dilakukan suatu badan atau lembaga yang memiliki nilai penting yang terkandung di dalamnya.

Dari pengertian diatas, dapat disimpulkan bahwa arsip adalah sebuah dokumen dari hasil kegiatan yang dibuat lalu disimpan karena memiliki nilai guna yang relevan dan dapat dipertanggungjawabkan kebenarannya. Sedangkan kearsipan adalah semua kegiatan dalam pengelolaan arsip yang dilakukan oleh lembaga atau organisasi yang memiliki arsip tersebut sehingga arsip dapat dengan mudah ditemukan dan tidak hilang nilai informasinya.

\section{Pembinaan Kearsipan}

\section{a. Penyusunan Penyediaan Pedoman Kearsipan}

Dalam mewujudkan pengelolaan arsip dinamis yang dilaksanakan secara kontinu, komprehensif dan terpadu maka diperlukan sebuah cara untuk dapat mengoptimalkannya, pembinaan kearsipan adalah salah satu alternatif yang dapat ditempuh untuk mencapai tujuan tersebut.

Penyusunan penyediaan pedoman kearsipan harus sejalan dengan Peraturan Pemerintah Nomor 28/ 2012 tentang Pelaksanaan Undang-Undang Nomor 43/ 2009 tentang Kearsipan, yakni pembinaan kearsipan bertujuan untuk membina penyelenggaraan sistem 
kearsipan nasional pada setiap pencipta arsip dan lembaga kearsipan sesuai dengan arah dan sasaran pembangunan nasional di bidang kearsipan sebagai literasi hak dan kewajiban warga negara (Faturahman, Kirana, Putra, Irawan, \& Kolne, 2019), Perka ANRI Nomor 22 / 2012 tentang Desain Pembinaan Kearsipan pada Pemerintah Daerah serta peraturan daerah yang berlaku yaitu perda Kabupaten Tangerang Nomor 1 Tahun 2015 tentang Penyelenggaraan Kearsipan.

Undang-undang dan peraturan tersebut merupakan bahan yang dijadikan sebagai pedoman pembinaan kearsipan yang dilakukan oelh ANRI ataupun Lembaga Kearsipan Daerah lainnya sehingga dapat memberikan kelancaran dan keberhasilan yang maksimal. Keberhasilan optimalisasi pengelolaan arsip dinamis melalui pembinaan kearsipan yang dapat dilihat berdasarkan faktor-faktor kearsipan yang baik yaitu penggunaan sistem penyimpanan secara tepat, fasilitas kearsipan memenuhi syarat dan petugas kearsipan yang memenuhi syarat (Widjaja, 1993:57).

\section{b. Sosialisasi Kearsipan}

Sosialisasi menurut Perka ANRI No. 23 Tahun 2012 adalah mekanisme untuk memberikan pemahaman kepada audiens dengan media yang digunakan dapat berupa forum diskusi, melalui media tayang materi kearsipan (video, film, dll), atau melalui media masa.

Secara umum tujuan sosialisasi adalah yakni untuk meningkatkan pengetahuan dan keterampilan bagi peserta agar mampu mengelola kearsipan secara efektif dan efisien dalam lingkungan unit kerja masingmasing serta meningkatkan mutu penyelenggaraan kearsipan melalui peningkatan kualitas sumber daya manusia sehingga arsip sebagai informasi dapat memberikan kontribusi terhadap terwujudnya penyelenggaraan kearsipan.

Lembaga Kearsipan Daerah Kabupaten/Kota sesuai Perda Kabupaten Tangerang Nomor 1 Tahun 2015, bertanggung jawab untuk melakukan kegiatan pembinaan kearsipan pada setiap Satuan Kerja Perangkat Daerah, Badan Usaha Milik Daerah, Kelurahan/Desa, Organisasi Politik, Organisasi Masyarakat, Perusahaan, dan Perorangan.

\section{c. Bimbingan Teknis Kearsipan}

Pada dasarnya kegiatan pelaksanaan bimbingan teknis merupakan kegiatan pendidikan dan pelatihan. Menurut Soekidjo Notoatmodjo, pendidikan dan pelatihan 
merupakan

upaya

untuk

mengembangkan sumber daya manusia, terutama untuk mengembangkan kemampuan intelektual dan kepribadian manusia (Notoatmodjo,2003:34).

Sedangkan

menurut

Sastrohadiwiryo (2003), pendidikan merupakan tugas untuk meningkatkan pengetahuan, pengertian, atau sikap para tenaga kerja sehingga dapat menyesuaikan pengetahuan umum dan pengertian tentang seluruh lingkungan kerja. Sedangkan pelatihan merupakan proses membantu para tenaga kerja untuk memperoleh efektivitas dalam pekerjaan mereka yang sekarang atau yang akan datang melalui pengembangan kebiasaan tentang pikiran, tindakan, kecakapan, pengetahuan dan sikap yang layak.

Dari penjelasan diatas dapat disimpulkan bahwa bimbingan teknis kearsipan merupakan bagian dari kegiatan pembinaan kearsipan yang penting dilakukan oleh ANRI atau Lembaga Kearsipan Daerah karena pada bimbingan teknis ini lah para peserta seperti arsiparis maupun pengelola arsip dapat meningkatkan pengetahuan dan kemampuan mereka tentang kearsipan dari mulai penciptaan hingga pemusnahan.
Dengan begitu arsiparis atau pengelola arsip yang mengikuti kegiatan ini dapat mempraktikannya di lingkungan kerja masing-masing guna terciptanya penataan arsip yang teratur dan sesuai dengan prosedur dan dapat menghindari masalah-masalah yang mungkin terjadi pada arsip mereka. Adapun pembinaan dibagi menjadi dua macam yakni pembinaan pengelolaan arsip dinamis dan pembinaan pengelola arsip statis yakni (Dinullah, 2008:34):

a. Pengelolaan arsip dinamis dengan sasaran untuk tingkat Provinsi terdiri dari SKPD, Kabupaten/Kota, dan BUMD. Sedangkan pada tingkat Kabupaten/Kota meliputi SKPD, Kecamatan, Kelurahan/Desa, BUMD, dan Sekolah.

b. Pengelolaan arsip statis dengan sasaran untuk lingan Lembaga Kearsipan Daerah

\section{d. Supervisi Kearsipan}

Supervisi adalah penilikan dan pengawasan. Kedua istilah ini menunjuk pada kegiatan bukan saja melihat apa yang terjadi dalam kegiatan keduanya seperti pemeriksaan, tetapi sudah mengadakan penilaian, yaitu mengidentifikasi hal-hal yang sudah baik sesuai yang diharapkan dan hal-hal yang belum karena belum sesuai dengan 
harapan (Arikunto, 2006:12). Sedangkan pengawasan kearsipan sendiri menurut Perka ANRI No. 38 Tahun 2015 tentang Pedoman Pengawasan Kearsipan adalah proses kegiatan dalam menilai kesesuaian antara prinsip, kaidah dan standar kearsipan dengan penyelenggaraan kearsipan. Supervisi juga dijelaskan dalam Peraturan Tetap ANRI yakni sebagai fungsi atau aktivitas membandingkan antara hasil yang dicapai dengan rencana yang dibuat di bidang manajemen arsip dinamis dan arsip statis.

Dari penjelasan diatas dapat disimpulkan bahwa supervisi atau pengawasan juga memiliki peran yang penting guna memberikan kelancaran dalam kegiatan pembinaan kearsipan. Dengan adanya supervisi ini, maka Lembaga Kearsipan Daerah sebagai pembina dapat terus memantau kepada para arsiparis atau pengelola arsip yang mereka bina agar saat arsiparis atau pengelola arsip melakukan kesalahan dapat segera diberikan masukan sehingga tetap sesuai dengan pedoman yang diberikan dan hal ini dapat dijadikan sebagai acuan untuk mengetahui tingkat keberhasilan dan kegagalan sebelum lanjut pada tahap terakhir yaitu tahap evaluasi.
Kegiatan ini bertujuan untuk mengetahui tingkat keberhasilan dan kegagalan serta untuk mendapatkan masukan bagaimana cara mengatasi permasalahan kearsipan yang ada. Sedangkan pelaksanaannya dilakukan dengan tatap muka dalam forum kelas atau dengan melaksanakan kunjungan ke unit kerja sasaran supervisi. Hasil dari pelaksanaan supervisi adalah berupa laporan berisi data (penghitungan nilai kuantitas standar, kualitas standar, kuantitas operasional, kualitas operasional, dan penghitungan pengujian spesifik) dengan menghitung nilai dan skor yang diperoleh oleh instansi di bidang penyelenggaraan kearsipan.

\section{e. Evaluasi.}

Evaluasi adalah suatu proses yang sistematis dan berkelanjutan untuk menentukan kualitas dari nilai dan arti daripada sesuatu, berdasarkan pertimbangan dan kriteria tertentu dalam rangka mengambil suatu keputusan (Arifin, 2013:5). Setelah menjelaskan apa itu evaluasi, Arifin juga menjelaskan bahwa:

a. Tujuan evaluasi adalah untuk menentukan kualitas terutama yang berkenaan dengan nilai dan arti.

b. Dalam proses evaluasi harus ada pemberian 
(judgement). Pemberian pertimbangan ini pada dasarnya merupakan konsep dasar evaluasi untuk menentukan nilai dan arti (worth and merit) dari sesuatu yang sedang dievaluasi.

c. Pemberian pertimbangan tentang nilai dan arti haruslah berdasarkan kriteria tertentu. Tanpa kriteria yang jelas, pertimbangan nilai dan arti yang diberikan bukanlah suatu proses yang dapat diklasifikasikan sebagai evaluasi.

\section{Metode Penelitian}

penelitian ini menggunakan jenis metode deskriptif, yakni mendeskripsikan seluruh gejala atau keadaan yang ada, yaitu keadaan gejala menurut apa adanya pada saat penelitian dilakukan. Sedangkan untuk pendekatan penelitiannya penulis menggunakan pendekatan kualitatif. Teknik pengumpulan data menggunakan data primer yaitu observasi, wawancara dan data sekunder yaitu literatur dan dokumentasi. Adapun teknik analisis data yaitu reduksi data, penyajian data dan penarikan kesimpulan.tuntas.

\section{Hasil dan Pembahasan}

\section{Analisis Kegiatan Pembinaan}

\section{Pengelolaan Arsip}

a. Penyusunan Penyediaan Pedoman Kearsipan

Disperpusip Kabupaten

Tangerang melaksanakan kegiatan pembinaan kearsipan pada pengelola arsip yang berada di kantor desa/kelurahan, kecamatan dan OPD yakni Dinas dan Badan sudah sesuai dengan penyusunan penyediaan pedoman kearsipan yang telah dituangkan kedalam Peraturan Daerah Kabupaten Tangerang Nomor 1 Tahun 2015 tentang penyelenggaraan kearsipan dan UU No. 43 tahun 2009 Pasal 8 tentang kearsipan yakni lembaga arsip di daerah kabupaten atau kota memiliki tugas untuk melaksanakan kegiatan pembinaan kearsipan kepada instansi ataupun SKPD yang berada di lingkup masing-masing daerah.

Pembinaan kearsipan oleh Disperpusip Kabupaten Tangerang dilakukan dengan dua metode yakni bimbingan teknis dan pendampingan secara langsung, hal ini sesuai dengan Peraturan Bupati Tangerang Nomor 71 Tahun 2016 tentang pengelolaan arsip dinamis pada BAB II penetapan kebijakan, pembinaan, dan organisasi kearsipan pengelolaan arsip dinamis pada pembinaan meliputi beberapa kegiatan diantaranya yaitu rapat koordinasi penyelenggaraan kearsipan, 
sosialisasi kearsipan, bimbingan dan konsultasi kearsipan, pemberian bantuan kearsipan, dan pendampingan.

b. Bimbingan Kearsipan

Bentuk lain dari pembinaan kearsipan yang dilakukan oleh Disperpusip Kabupaten Tangerang yakni berupa bimbingan teknis, kegiatan tersebut dilakukan pada kantor desa/kelurahan, kecamatan, dan OPD. Namun bimbingan teknis lebih terpaku pada OPD yakni Dinas dan Badan yang berada di lingkup wilayah Kabupaten Tangerang, salah satu peserta dari kegiatan tersebut yakni Dinas Pendidikan Kabupaten Tangerang.

Kegiatan yang dilakukan oleh Disperpusip Kabupaten Tangerang hanya berbeda secara penyebutan, namun dilihat dari penjelasan dan rangkaian kegiatan tersebut, pembinaan kearsipan dalam bentuk bimbingan teknis ini merupakan kegiatan sosialisasi kearsipan yang dijelaskan dalam Perka ANRI No. 23 Tahun 2012. Dengan begitu, kegiatan pembinaan kearsipan dalam bentuk bimbingan teknis tersebut sudah sesuai dengan Perka ANRI No. 23 Tahun 2012, yakni mekanisme untuk memberikan pemahaman kepada audiens dengan media yang digunakan dapat berupa forum diskusi, melalui media tayang materi kearsipan (video, film, dll), atau melalui media masa.

Namun berdasarkan tujuan dari kegiatan sosialisasi kearsipan tersebut, Disperpusip Kabupaten Tangerang belum berhasil yakni untuk meningkatkan pengetahuan dan keterampilan peserta kegiatan sosialisasi kearsipan dalam mengelola arsip secara efektif dan efisien di ruang lingkup kerja mereka.

Adapun dalam pelaksanaan kegiatan pembinaan kearsipan berupa bimbingan teknis yang diberikan oleh Disperpusip Kabupaten Tangerang belum berjalan dengan baik. Hal ini disebabkan oleh materi yang diberikan pada saat kegiatan tersebut berlangsung dirasa belum dapat mengedukasi secara utuh oleh para pengelola arsip yang notabene bukan berasal dari latar belakang pendidikan kearsipan, hal ini dirasa belum cukup jika hanya melalui proses pemberian materi dalam bentuk tampilan slide di layar proyektor, selain itu waktu yang terbatas juga dapat mempengaruhi pengelola arsip yang merasa belum puas dalam menerima penjelasan dari materi yang disampaikan.

Menurut analisis penulis dari sosialisasi kearsipan dan hasil yang ditemui di lapangan kegiatan bimbingan 
teknis yang telah dilaksanakan oleh Disperpusip Kabupaten Tangerang kesimpulannya adalah bahwa kegiatan tersebut belum berhasil diterapkan pada pengelola arsip yang ada di OPD salah satunya yakni Dinas Pendidikan, hal ini dikarenakan waktu yang belum cukup untuk membuat seorang pengelola arsip atau orang yang berkerja dalam mengelola arsip di suatu organisasi namun bukan berasal dari latar belakang pendidikan kearsipan dapat memahami betul tentang bagaimana pengelolaan arsip yang baku dan baik.

\section{c. Pendampingan}

Pelaksanaan

pembinaan kearsipan dalam bentuk pendampingan ini berbeda dari bimbingan teknis, pendampingan ini adalah bentuk dari tahap lanjut dari kegiatan bimbingan teknis yakni praktek langsung yang dilakukan pada pengelola arsip di kantor desa/kelurahan dan kecamatan yang didampingi oleh arsiparis dari Disperpusip Kabupaten Tangerang.

$\begin{array}{rrr}\text { Sesuai } & \text { dengan } & \text { teori yang } \\ \text { dikemukakan } & \text { oleh } & \text { Soekidjo }\end{array}$
Notoatmodjo, bimbingan teknis yang merupakan gabungan dari kegiatan pendidikan dan pelatihan yakni upaya untuk mengembangkan sumber daya manusia, terutama untuk mengembangkan kemampuan intelektual dan kepribadian manusia.

Pada hasil penelitian di lapangan, penulis mendapatkan kesimpulan bahwa kegiatan pendampingan tersebut sudah berhasil dilakukan oleh Disperpusip Kabupaten Tangerang pada pengelola arsip yang ada di Desa Bitung Jaya dan Kelurahan Bunder. Hal ini dikarenakan kegiatan tersebut dilakukan secara langsung dengan menangani permasalahan yang ada dalam pengelolaan arsip di kantor desa/kelurahan tersebut. Dengan begitu pengelola arsip dapat dengan mudah memahami materi yang telah diberikan kepadanya serta dapat mengimplementasikan secara langsung ilmu yang didapatkan dalam bimbingan teknis maupun pendampingan pada kegiatan pengelolaan arsip di ruang lingkup kerja mereka.

Selain itu, kegiatan pembinaan kearsipan dalam bentuk pembinaan ini dapat dikatakan berhasil karena kegiatan ini telah sesuai dengan tujuan dari adanya kegiatan pembinaan kearsipan yakni meningkatkan pemahaman dan kesadaran tentang pentingnya arsip bagi kehidupan bermasyarakat, berbangsa, dan bernegara, serta meningkatnya kemampuan pengelolaan arsip. 


\section{d. Supervisi/Pengawasan Kearsipan}

Disperpuip Kabupaten Tangerang melakukan supervisi/pengawasan atau yang disebut juga monitoring kepada pengelola arsip yang ada di kantor desa/kelurahan yang telah diberikan pembinaan kearsipan dalam bentuk pendampingan, hal ini dilakukan untuk mengetahui progress dari hasil pembinaan kearsipan berupa pendampingan secara langsung dan berpartisipasi secara aktif sebagai bentuk transparansi masyarakat di desa (Faturahman, 2018).

Sesuai dengan teori yakni supervisi adalah sesuatu hal yang menunjuk pada kegiatan bukan saja melihat apa yang terjadi dalam kegiatan keduanya seperti pemeriksaan, tetapi sudah mengadakan penilaian, yaitu mengidentifikasi hal-hal yang sudah baik sesuai yang diharapkan dan hal-hal yang belum karena belum sesuai dengan harapan.

Menurut analisis penulis dari penjelasan di atas tentang supervisi atau monitoring yang telah dilakukan oleh Disperpusip Kabupaten Tangerang kesimpulannya adalah Disperpusip Kabupaten Tangerang sudah melakukan kegiatan supervisi atau monitoring kepada pengelola arsip secara langsung di kantor desa/kelurahan dengan memberi nilai dan saran kepada pengelola arsip dalam progress pengelolaan arsip yang telah mereka terapkan.

\section{e. Evaluasi}

Untuk mengetahui bagaimana penerapan pengelolaan arsip di masingmasing desa/kealurahan yang setelah dilaksanakan oleh Disperpusip Kabupaten Tangerang perlu dilakukan adanya evaluasi.

Namun berdasarkan hasil penelitian di lapangan penulis menemukan bahwa di tahun ini Disperpusip Kabupaten Tangerang tidak melakukan kegiatan evaluasi, namun kegiatan ini digantikan oleh kegiatan monitoring yang memiliki konsep yang hamper sama dengan monitoring. Hal ini disebebkan oleh DPA atau Dokumen Penggunaan Anggaran yang berbeda. Namun dari adanya kegiatan pembinaan kearsipan, Disperpusip Kabupaten Tangerang mengharapkan output dan outcome yang dihasilkan dapat sesuai dengan yang mereka harapkan agar dapat mewujudkan visi dari Disperpusip Kabupaten Tangerang yakni “Terwujudnya Perpustakaan Terunggul di Provinsi Banten dan Tertib Administrasi Tata Kearsipan Daerah 2018". dan menyebalkan. 


\section{f. Analisis Kegiatan Pembinaan}

\section{Pengelolaan Arsip}

Berdasarkan hasil penelitian yang telah dijabarkan, dapat disimpulkan bahwa dari dua macam kegiatan pembinaan pengelolaan arsip yang telah dilaksanakan oleh Dinas Perpustakaan dan Arsip Kabupaten Tangerang terdapat kekurangan dan kelebihan yang miliki masing-masing kegiatan tersebut, yakni sebagai berikut:

Tabel 1. Kekurangan dan Kelebihan Pembinaan Pengelolaan Arsip

\begin{tabular}{|c|c|c|c|}
\hline \multicolumn{2}{|c|}{ Bimbingan Teknis } & \multicolumn{2}{|c|}{ Pendampingan } \\
\hline Kekurangan & Kelebihan & Kekurangan & Kelebihan \\
\hline $\begin{array}{l}\text { Kegiatan tidak } \\
\text { bervariasi }\end{array}$ & $\begin{array}{c}\text { Penjelasan yang } \\
\text { detail }\end{array}$ & $\begin{array}{c}\text { Waktu pelaksanaan } \\
\text { yang sering } \\
\text { bentrok dengan } \\
\text { kegiatan pelayanan }\end{array}$ & $\begin{array}{l}\text { Mudah dipahami } \\
\text { dengan praktek } \\
\text { secara langsung }\end{array}$ \\
\hline $\begin{array}{c}\text { Waktu } \\
\text { pelaksanaan } \\
\text { yang singkat }\end{array}$ & $\begin{array}{c}\text { Semua } \\
\text { pengelola arsip } \\
\text { OPD hadir } \\
\text { selaku peserta } \\
\text { kegiatan }\end{array}$ & $\begin{array}{l}\text { Hanya beberapa } \\
\text { pengelola arsip di } \\
\text { desa/kelurahan } \\
\text { yang diberi } \\
\text { pendampingan } \\
\text { pertahun }\end{array}$ & $\begin{array}{c}\text { Tema materi } \\
\text { pendampingan } \\
\text { fleksibel sesuai } \\
\text { permasalahan yang } \\
\text { terjadi di } \\
\text { desa/kelurahan }\end{array}$ \\
\hline $\begin{array}{l}\text { Tidak ada } \\
\text { monitoring } \\
\text { sebagai } \\
\text { penilaian } \\
\text { progress dari } \\
\text { kegiatan } \\
\text { tersebut }\end{array}$ & $\begin{array}{l}\text { Lebih hemat } \\
\text { anggaran }\end{array}$ & $\begin{array}{c}\text { Anggaran yang } \\
\text { digunakan lebih } \\
\text { besar dari } \\
\text { Bimbingan Teknis }\end{array}$ & $\begin{array}{c}\text { Setelah } \\
\text { pendampingan, } \\
\text { Dispeprusip } \\
\text { melakukan } \\
\text { monitoring sebagai } \\
\text { penilaian atas } \\
\text { progress dari hasil } \\
\text { kegiatan } \\
\text { pendampingan serta } \\
\text { pemberian saran } \\
\text { dalam pengelolaan } \\
\text { arsip yang baik }\end{array}$ \\
\hline $\begin{array}{l}\text { Lebih sulit } \\
\text { dipahami } \\
\text { peserta }\end{array}$ & $\begin{array}{c}\text { Tidak } \\
\text { membutuhkan } \\
\text { banyak tenaga } \\
\text { dalam } \\
\text { pelaksanaannya }\end{array}$ & $\begin{array}{c}\text { Membutuhkan } \\
\text { tenaga yang lebih } \\
\text { dalam } \\
\text { pelaksanaannya }\end{array}$ & $\begin{array}{c}\text { Lebih efektif } \\
\text { dibandingkan } \\
\text { Bimbingan Teknis }\end{array}$ \\
\hline
\end{tabular}

Kegiatan pembinaan pengelolaan arsip yang telah dilaksanakan dalam dua metode ini memiliki kekurangan serta kelebihan yang dimilikinya, berdasarkan 
data tabel diatas dapat diketahui bahwa kegiatan pendampingan lebih berhasil mencapai tujuan dari kegiatan pembinaan yang telah diberikan Disperpusip Kabupaten Tangerang terhadap pengelola arsip yang ada di desa/kelurahan dibandingkan dengan kegiatan pembinaan dalam bentuk bimbingan teknis jika melihat dari prinsip efektif dan efisien.

\section{Kendala dalam Pembinaan}

\section{Pengelolaan Arsip}

Berdasarkan hasil data yang didapat bahwa terdapat kendala yang dihadapi para pengelola arsip dalam Pelaksanaan Pembinaan Pengelolaan Arsip Oleh Disperpusip Kabupaten Tangerang. Berikut adalah kendalakendala yang sering terjadi yakni:

\section{a. Sumber Daya Manusia}

Sumber daya manusia dalam hal ini adalah pengelola arsip sebagai peserta dan target dari pembinaan kearsipan yang dilakukan oleh Disperpusip Kabupaten Tangerang. Pada kasus yang terjadi di tiap kantor desa/kelurahan dan OPD berbeda-beda, salah satunya yang terjadi di Dinas Pendidikan Kabupaten Tangerang dan Desa Bitung Jaya.

Kendala yang terjadi disebabkan oleh kesalahan dalam penunjukan tugas untuk mengikuti kegiatan pembinaan kearsipan dalam bentuk bimbingan teknis, hal ini terjadi karena ketidakjelasan tupoksi (tugas pokok dan fungsi) antara PNS dan non-PNS di Dinas Pendidikan Kabupaten Tangerang. Sedangkan pada Desa Bitung Jaya juga mengalami hal serupa, namun hal ini disebabkan oleh belum adanya tenaga pengelola arsip yang bertugas dalam mengelola arsip yang ada di Desa Bitung Jaya, maka dalam mengikuti kegitan pembinaan kearsipan dalam bentuk bimbingan teknis dan pendampingan diikuti oleh Kepala Urusan Bidang Perencanaan.

Penulis dapat menyimpulkan bahwa dengan terjadinya kendala seperti yang telah dijelaskan di atas, maka hal ini akan berdampak pada pengelolaan arsip yang ada di Desa Bitung Jaya dan Dinas Pendidikan Kabupaten Tangerang karena tidak tersampaikannya materi yang disampaikan pada saat bimbingan teknis serta kegiatan tersebut belum tepat sasaran seperti yang diharapkan oleh Disperpusip Kabupaten Tangerang.

b. Manajemen Pengelolaan Arsip

Berdasarkan dari hasil penelitian di lapangan dan didukung oleh hasil wawancara maka penulis dapat menyimpukan bahwa kendala yang 
terjadi dalam manajemen pengelolaan arsip yang terjadi pada Desa Bitung Jaya, Kelurahan Bunder dan Dinas Pendidikan Kabupaten Tangerang yakni sebagai berikut:

\section{1) Penyimpanan Arsip}

Penyimpanan arsip yang ada di pada Desa Bitung Jaya, Kelurahan Bunder dan Dinas Pendidikan Kabupaten Tangerang belum sesuai dengan standar penyimpanan arsip yakni arsip yang disimpan belum dipisahkan sesuai nomor klasifikasi arsip sesusi dengan masalah dan sub masalah dari masing-masing surat.

Kondisi ini pula diperparah dengan tidak tersedia secara lengkap dari sarana dan prasarana dalam penyimpanan arsip mulai dari boks arsip sampai dengan rak arsip itu sendiri. Kendala yang dihadapi dalam sarana dan prasarana pun hampir sama terjadi di Desa Bitung Jaya, Kelurahan Bunder dan Dinas Pendidikan Kabupaten Tangerang yakni tidak tersedia dan belum menerapkannya standarisasi kelengkapan sarana dan prasarana dalam pengelolaan arsip tersebut.

Hal tersebut belum sesuai dengan teori Barthos yakni perlengkapan penyimpanan surat yakni sebagai berikut folder (map), guide (penunjuk dan pemisah), tickler-file (berkas pengingat), filing cabinet (lemari arsip), rak-arsip, boks arsip, kartu kendali, lembar pengantar surat rahasia dan surat rutin, lembar disposisi dan konsep, kartu pinjam arsip, dan kartu tunjuk silang.

Menurut analisis penulis dari beberapa macam sarana dan prasarana dalam perlengkapan penyimpanan arsip kesimpulannya adalah masih banyak kantor desa/kelurahan dan OPD yang masih belum memenuhi sarana dan prasarana dalam kegiatan penyimpanan arsip. Hal ini disebabkan oleh belum adanya anggaran yang disediakan oleh kantor desa/kelurahan dan OPD dalam memenuhi sarana dan prasarana dalam penyimpanan arsip demi kelancaran kegiatan pengelolaan arsip yang ada di lingkup kerja mereka.

2) Pemeliharaan Arsip

Kendala lain yang sering dihadapi di semua desa/kelaurahan dan OPD salah satunya yakni pada Desa Bitung Jaya, Kelurahan Bunder dan Dinas Pendidikan Kabupaten Tangerang adalah belum adanya Standar Operasional Prosedur atau 
SOP dalam merawat ataupun memelihara arsip yang dimilikinya.

Hal ini belum sesuai dengan teori Wursanto yakni usaha pemeliharaan arsip berupa melindung, mengatasi, mencegah dan mengambil langkah-langkah, tindakan-tindakan yang bertujuan untuk menyelamatakn arsip-arsip berikut informasinya serta menjamin kelangsungan hidup arsip dari pemusnahan yang sebenarnya tidak diinginkan.

Menurut analisis penulis dari penjelasan di atas tentang kegiatan pemeliharaan di Desa Bitung Jaya, Kelurahan Bunder dan Dinas Pendidikan Kabupaten Tangerang kesimpulannya adalah kegiatan tersebut belum dilakukan secara langsung pada arsip-arsip yang disimpan mereka sehingga arsip yang disimpan pun dapat terkena penyakit kertas salah satunya yang dikarenakan faktor internal maupun faktor eksternal.

\section{Kesimpulan}

Berdasarkan hasil penelitian dan pembahasan yang telah diuraikan sebelumnya mengenai Analisis Pembinaan Pengelolaan Arsip Oleh Dinas Perpustakaan dan Arsip Kabupaten
Tangerang dapat disimpulkan beberapa hal sebagai berikut:

1. Disperpusip Kabupaten Tangerang melakukan kegiatan pembinaan kearsipan dengan dua metode yakni dengan cara bimbingan teknis dan pendampingan yang dilakukan secara langsung kepada pengelola arsip. Sasaran dari kedua kegiatan tersebut berbeda, hal ini dikarenakan kegiatan tersebut telah ditetapkan di dalam Dokumen Penggunaan Anggaran atau DPA yang dimiliki oleh Disperpusip Kabupaten Tangerang, maka dari itu kegiatan pembinaan kearsipan berupa bimbingan teknis dilakukan dengan cara klasikal dalam waktu satu hari yang diikuti oleh seluruh Organisasi Perangkat Daerah atau OPD yakni salah satunya Dinas Pendidikan Kabupaten Tangerang, namun kegiatan bimbingan teknis ini juga dilakukan kepada kantor desa/kelurahan dan kecamatan yang berada di wilayah Kabupaten Tangerang. Kegiatan bimbingan teknis hanya sebatas pelatihan dengan mengumpulkan pengelola arsip di sebuah ruangan atau auladengan penyampaian materi kearsipan menggunakanan alat bantu berupa proyektor dan slide 
power point dan sarana prasarana seperti boks arsip, folder, sekat, dan lain-lain yang disampaikan oleh salah satu arsiparis dari Disperpusip Kabupaten Tangerang. Selain itu, kegiatan pembinaan kearsipan juga dilakukan dalam bentuk pendampingan secara langsung juga diberikan kepada 2-3 desa/kelurahan yang sudah dipilih oleh kecamatan untuk diberikan kegiatan pendampingan yang dilakukan oleh Disperpusip Kabupaten Tangerang, salah satu peserta kegiatan tersebut yakni Desa Bitung Jaya dan Kelurahan Bunder yang berada di Kecamatan Cikupa Kabupaten Tangerang. Kegiatan tersebut berupa praktek secara langsung dengan menata arsip yang ada di kantor desa/kelurahan dengan tema "Pengelolaan Arsip Dinamis Inaktif". Kedua macam kegiatan tersebut memiliki kekurangan serta kelebihan masingmasing yang dimilikinya, berdasarkan tabel tersebut dapat disimpulkan bahwa kegiatan pendampingan lebih berhasil mencapai tujuan dari kegiatan pembinaan yang telah diberikan Disperpusip Kabupaten Tangerang terhadap pengelola arsip yang ada di desa/kelurahan dibandingkan dengan kegiatan pembinaan dalam bentuk bimbingan teknis jika melihat dari prinsip efektif dan efisien.

2. Pembinaan kearsipan yang dilakukan oleh Disperpusip Kabupaten Tangerang pada Desa Bitung Jaya, Kelurahan Bunder, dan Dinas Pendidikan Kabupaten Tangerang memiliki kendala yang hampir sama yaitu Sumber Daya Manusia (SDM) yang diikutsertakan dalam kegiatan pembinaan kearsipan tidak sesuai dengan tugas sebagai pengelola arsip serta tenaga pengelola arsip yang belum dimiliki oleh Desa Bitung Jaya, selain itu kendala juga terjadi dalam manajemen pengelolaan arsip yang masih belum maksimal dalam hal penyimpanan arsip dengan sarana dan prasarana yang belum memadai serta pemeliharaan arsip yang dilakukan oleh tiap-tiap organisasi belum sesuai dengan standar karena belum memiliki SOP yang berlaku dalam merawat maupun memelihara arsip yang disimpan mereka. 


\section{Daftar Pustaka}

Arifin, Z. (2013). Evaluasi Pembelajaran:

Prinsip, Teknik, Prosedur. Bandung: Remaja Rosdakarya.

Arikunto, S. (2006). Dasar-Dasar

Supervisi. Jakarta: Rineka Cipta.

Barthos, B. (2012). Manajemen

Kearsipan Untuk Lembaga

Negara, Swasta, dan Perguruan

Tinggi. Jakarta: Bumi Aksara.

Basuki, S. (1996). Pengantar Kearsipan.

Jakarta: Universitas Terbuka.

Dinullah, A.,H. (2008). Kegiatan

Pembinaan Kearsipan di SUDIN

PUSIP Kota Administrasi Jakarta

Barat Terhadap SKPD dan UKPD.

Jakarta: UIN Syarif Hidayatullah

Jakarta.

Faturahman, B. M. (2018). Aktualisasi

Nilai Demokrasi dalam Perekrutan dan Penjaringan Perangkat Desa. SOSPOL, 4(1), 132-148.

Faturahman, B. M., Kirana, C. A. D., Putra, D. D., Irawan, A., \& Kolne, S. V. (2019). Strengthening Village Culture Literacy in the National Development. Jurnal Sospol, 5(1), 61-81.

Notoatmodjo, S. (2003). Pengembangan

Sumber Daya Manusia. Jakarta:

Rineka Cipta.
Peraturan Daerah Kabupaten Tangerang

Nomor 1 Tahun 2015 Tentang Penyelenggaraan Kearsipan

Peraturan Kepala ANRI No. 23 Tahun 2012 tentang Standar Fungsi Lembaga Kearsipan Daerah BAB IV Hal. 18 Poin 3.a

Peraturan Kepala ANRI No. 38 Tahun 2015 tentang Pedoman Pengwasan Kearsipan

Peraturan Pemerintah Republik Indonesia Nomor 28 Tahun 2012 tentang Pelaksanaan UndangUndang Nomor 43 Tahun 2009 tentang Kearsipan

Peraturan Tetap ANRI No. 63 Tahun 2010 tentang Bimbingan dan Supervisi Penerapan Sistem Kearsipan Lembaga Negara dan Lembaga Tingkat Pusat Lainnya. Republik Indonesia. Undang-Undang Republik Indonesia Nomor 43 Tahun 2009 tentang Kearsipan Sastrohadiwiryo, S. (2003). Manajemen Tenaga Kerja Indonesia. Jakarta: Bumi Aksara.

Widjaja, A.W. (1993). Administrasi Kearsipan Suatu Pengantar. Jakarta: Raja Grafindo 